\title{
TRÊS MOMENTOS DO ROMANCE HISTÓRICO DE JOSÉ SARAMAGO
}

\author{
Aparecida de Fátima Bueno
} Universidade Federal de Viçosa

\section{Introdução}

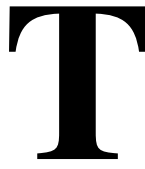

eresa Cristina Cerdeira da Silva, na Introdução de seu livro José Saramago. Entre a bistória e a ficção: uma saga de portugueses, afirma que

A questão sobre a qual queremos reflectir ao analisar três romances de José Saramago é justamente esta: em que medida a postura desses romances, voluntariamente histórica, como confessa o autor, é, senão inovadora, pelo menos mais radical do que outros projetos ficcionais que, em Portugal, transitam também para o discurso do vero sem se contentar com o verosímil. Formulando mais claramente a questão, poderíamos falar aqui de uma História que se quer ficção e não apenas de uma ficção que compactua com a História? ${ }^{1}$

O livro de Cerdeira da Silva, ponto de referência aos que se aventurarem a estudar a obra de José Saramago, analisa os seguintes romances: Memorial do convento, O ano da morte de Ricardo Reis e Levantado do chão, respeitando não a ordem de publicação, mas privilegiando o "tempo referencial/histórico que cobrem". ${ }^{2}$ Teresa Cristina destaca ainda, a respeito da obra do escritor português, que

\footnotetext{
${ }^{1}$ SILVA, 1989, p.26.

${ }^{2}$ SILVA, 1989, p.27.
} 
(...) não se trata de um texto que, enquanto ficção, tangencia o histórico porque utiliza informações verídicas que, eventualmente, são objecto da História, mas de um discurso que, em sua execução e propósitos, se revela organizador da História por intermédio do ficcional. O texto pretende-se histórico e como tal se constitui. ${ }^{3}$

Sem dúvida alguma é bastante pertinente a escolha de Cerdeira da Silva quando procura analisar os textos de Saramago enfocando a sua relação com o discurso histórico. O próprio autor de Memorial do convento, comentando sobre a importância da história em suas obras, afirmara, em uma de suas entrevistas, que

Tenho agora alguns planos de trabalho, resta saber se terei tempo de organizá-los. É uma espécie de necessidade de corrigir a própria história, quer dizer, usar a ficção como corretor da história (...).

A história que nos é ensinada dá-nos apenas um percurso, quando são possíveis mil outros. É essa a minha atitude em relação ao passado. Ver o que há mais além daquilo que já está dito e, se for possível, corrigir e pôr outra coisa no seu lugar. ${ }^{4}$

Por certo falar do romance histórico de José Saramago permitiria abordar, além dos livros analisados por Cerdeira da Silva, ${ }^{5}$ outros dois romances do escritor português: trata-se de a História do cerco de Lisboa e de O Evangelho segundo Jesus Cristo, publicados respectivamente em 1989 e 1991. Porém, na leitura que pretendemos fazer dessa obra, optamos por selecionar especificamente os seguintes romances: Memorial do convento, O ano da morte de Ricardo Reis e O Evangelho segundo Jesus Cristo.

O motivo desse recorte é que, mais do que a forma como Saramago desconstrói os períodos históricos retratados em sua obra,

${ }^{3}$ SILVA, 1989, p.26.

${ }^{4}$ DUARTE et alii, 1986-1988, p.94-95.

${ }^{5}$ O livro de Teresa Cristina Cerdeira da Silva, publicação de sua tese de doutorado defendida na UFRJ em 1987, veio a lume dois anos depois da defesa, em 1989. Por esse motivo óbvio, a História do cerco de Lisboa e O Evangelho segundo Jesus Cristo não poderiam ser contemplados em sua análise. 
nos interessa analisar principalmente a maneira como este autor desmistifica seja personagens importantes da história pátria, como D. João V, de Memorial do convento, seja personagens literárias (ou histórico-literárias) como Fernando Pessoa, seu heterônimo Ricardo Reis, e Camões, citando apenas os nomes dos escritores mais conhecidos entre os que serão revisitados de maneira crítica em $O$ ano da morte de Ricardo Reis. Também nos interessa a maneira como Saramago desmistifica um personagem importantíssimo para a civilização ocidental, que é tributária do cristianismo. Estamos obviamente nos referindo ao protagonista de O Evangelho segundo Jesus Cristo.

Levantado do Chão e História do cerco de Lisboa são livros que poderiam estar sendo contemplados numa leitura que priorizasse verificar como Saramago utiliza a ficção como corretor da história. O primeiro deles narra a saga de trabalhadores rurais alentejanos, do período que vai, aproximadamente, da proclamação da república em Portugal, em 1910, até a Revolução dos Cravos, em 1974; já o segundo, apesar de, inicialmente, ter sua trama focada nos tempos atuais, tem um personagem, Raimundo Silva, que começa a escrever um romance cujo título é o mesmo do livro de que faz parte, no qual conta, portanto, a história do cerco de Lisboa, fato histórico ocorrido no século XII, no início da constituição da nacionalidade portuguesa. Os dois livros são certamente exemplares do modus operandi de José Saramago, ou seja, da maneira como o escritor português aborda a história em suas obras.

Em Levantado do chão, de 1981, Saramago, num processo que será recorrente em suas obras posteriores, dará voz aos que em geral não são contemplados pela história oficial, a arraia miúda, usando aqui uma expressão bem portuguesa. Na História do cerco de Lisboa, através da história que narra Raimundo Silva, Saramago vai deliberadamente contestar um fato histórico considerado inquestionável, qual seja, que Afonso Henriques, primeiro rei de Portugal, precisou da ajuda dos cruzados para vencer os mouros, durante o cerco que fez para conquistar a cidade de Lisboa. Se a História oficial diz que sim, que o rei precisou dessa ajuda, o personagem de José 
Saramago vai negar essa versão dos fatos e, através do romance que está escrevendo, procurar contestá-la. Portanto, neste romance temos um outro processo também recorrente na sua escrita, e do qual já falamos, que é ver o que há mais além daquilo que já está dito e, se for possível, corrigir e pôr outra coisa no seu lugar, pois esse autor considera que

(...) essa nova operação introduzirá, digamos, uma instabilidade, uma vibração, precisamente causadas pela perturbação do que poderia ter sido, quiçá tão útil a um entendimento do nosso presente como a demonstração efectiva, provada e comprovada do que realmente aconteceu. $^{6}$

Se Levantado do chão e História do cerco de Lisboa se enquadram dentro da perspectiva que norteia boa parte da obra de Saramago, que é a sua preocupação em substituir o que foi pelo que poderia ter sido, ou seja, corrigir a bistória, esses romances, entretanto, não são exemplares de um outro procedimento recorrente desse escritor, e do qual já falamos, que é o de dessacralizar importantes personagens históricas. Na primeira dessas obras não há exatamente um grande nome sendo desmistificado, pois são as instituições - o Estado Novo, a Igreja Católica que o apóia, e o Latifúndio - que estão sob o olhar crítico de Saramago. Em História do cerco de Lisboa, apesar de o rei fundador da nacionalidade, Afonso Henriques, aparecer como personagem, ele não é o centro das atenções do narrador do romance. ${ }^{7}$ Em função da opção de leitura aqui feita, excluímos desta análise esses dois romances, pois, mesmo sendo também obras representativas da

${ }^{6}$ SARAMAGO, 1990, p.19.

${ }^{7}$ Apesar de esse rei ser colocado num segundo plano da narrativa - pois ao focar o episódio do cerco de Lisboa, o narrador privilegia, através da história e da participação de um soldado, Mogueime, o esforço dos que contribuíram para um feito importante da história pátria, mas que não aparecem nos compêndios históricos que relatam o episódio - esse rei não chegar a ser desmistificado, como é, por exemplo, o D. João V de Memorial do convento. 
maneira como o escritor português transita entre a ficção e a História, eles porém não são exatamente exemplares do modo como ele desmistifica personagens históricos importantes. Como nosso interesse é trabalhar principalmente com esse aspecto da obra de José Saramago, ou seja, como este autor desconstrói os mitos, sejam eles pátrios ou não, aqui vai, portanto, o motivo do recorte feito.

\section{O convento e a passarola}

A história oficial registra que a "mais importante realização pessoal de D. João V foi o projecto de construção de um edifício gigantesco, de proporções que excediam de longe tudo quanto até então se edificara em Portugal: o Palácio-Convento de Mafra". ${ }^{8}$ José Saramago vai utilizar essa construção como fio desencadeante da narrativa de Memorial do convento, de 1982. Porém, de fato, este livro vai nos contar a história de duas construções: a do convento de Mafra e a da passarola voadora do padre Bartolomeu Lourenço de Gusmão.

Se o mote inicial da narrativa é o motivo que levou à contrução desse monumento faraônico erguido no século XVIII, já que, segundo ficou registrado, "Deve-se a construção do convento de Mafra ao rei D. João V, por um voto que fez se lhe nascesse um filho", ${ }^{9}$ a construção que privilegiará, todavia, e que ocupa boa parte das páginas do romance, é a da passarola. Apenas quando a saga da máquina de voar do padre Bartolomeu chega ao fim, é que se inicia a narrativa da construção do convento, como adverte Teresa Cristina Cerdeira da Silva:

O interessante é que, mais uma vez, é a passarola que orienta a narrativa. Na sua viagem conduz os personagens, o narrador e a própria narrativa a Mafra e, tendo chegado ao seu paroxismo a epopeia dos ares,

\footnotetext{
${ }^{8}$ SARAIVA, 1978, p.221.

${ }^{9}$ SARAMAGO, 1983, p.257.
} 
cede ela espaço para que seja narrada - só então-a construção do Convento de Mafra. (...) só então começa, realmente, o memorial do convento. ${ }^{10}$

O padre Bartolomeu de Gusmão, conhecido pela alcunha de "Voador", nascido no Brasil provavelmente em 1685, e falecido na Espanha em 1724, freqüentou, de fato, a corte de D. João V, tendo dirigido ao rei "uma petição em que anunciava ter descoberto um instrumento para se andar pelo ar da mesma sorte que pela terra e pelo mar", sendo-lhe concedido pelo rei um privilégio para prosseguir as suas investigações.

A história oficial registra que Bartolomeu Lourenço obteve sucesso, em pelo menos duas de suas experiências, pois conseguiu que um balão, por ele projetado, subisse "cerca de 4,5 m, até ao teto da sala", e, logo em seguida, um outro "instrumento de voar", também por ele criado, teria elevado-se a "bastante altura".

Se o que nos restam nos documentos históricos do período sobre Frei Bartolomeu de Gusmão são esses dados, em seu romance Saramago se apropria do mito, "de que o "Voador" chegara a realizar, ele próprio, uma ascensão na máquina que construíra para esse efeito", ${ }^{11}$ já que em Memorial do convento a passarola realmente existiu e voou, carregando consigo o seu inventor.

Como vemos, em relação às duas construções, Saramago dará prioridade à que é fruto do sonho e da imaginação, deixando para segundo plano o relato da construção do convento de Mafra. De forma análoga, agirá em relação aos personagens históricos presentes na obra - excetuando-se o padre Bartolomeu de Gusmão -, o autor de Memorial do convento os colocará em segundo plano e terá para com eles uma atitude de irreverência.

O rei e a rainha, personagens centrais no primeiro capítulo, logo são colocados de lado, pois um outro casal é que realmente protagonizará o romance: um soldado maneta, Baltasar Sete-Sóis, e

\footnotetext{
${ }^{10}$ SILVA, 1989, p.66.

${ }^{11}$ Cf. SERRÃO, 1971, p.408-9.
} 
uma mulher capaz de ter visões muito especiais, e que a ele se une, de nome Blimunda. Os dois se juntam ao padre Bartolomeu na construção da passarola. Sobre o poder de Blimunda, o padre Bartolomeu diz "que se trata de um grande mistério, voar é uma coisa simples comparando com Blimunda”. ${ }^{12}$ Os três formam uma nova trindade, e que será comparada à Santíssima Trindade pelo próprio padre Lourenço de Gusmão:

(...) Eu e Baltasar temos a mesma idade, trinta e cinco anos, não poderíamos ser pai e filho naturais, isto é, segundo a natureza, mais facilmente irmãos, (...) Quanto ao espírito, Esse seria Blimunda, talvez seja ela a que mais perto estaria de ser parte numa trindade não terrenal (...). ${ }^{13}$

O relacionamento de Baltasar e Blimunda fará contraponto ao do rei e da rainha, pois, enquanto o destes é um casamento de conveniência, para cumprir interesses do Estado, Baltasar e Blimunda vivem uma união verdadeira, ligados que estão pela paixão. A esse respeito, Cerdeira da Silva coloca que

Ao encontro sexual, com fins procriativos, do rei e da rainha, Baltasar e Blimunda opõem os corpos nus, o gozo mútuo, o jogo erótico e a ausência de filhos. A esterilidade da rainha precisava de remédio e até da magia que só a religião podia oferecer, na troca de favores com a divindade: toma lá o convento, dá cá o herdeiro. A união de Baltasar e Blimunda não se ressente da ausência de um herdeiro. Talvez porque tenham descoberto a plenitude no encontro a dois, priorizando o erotismo e não a fertilidade, talvez porque não tenham herança a deixar, pois a que deixariam era a de um saber maior que o do vulgo, novo demais para lançar frutos imediatos. ${ }^{14}$

Saramago também desconstrói a imagem do rei. Se este ficou conhecido como rei "pedreiro e arquiteto", em função das obras faraônicas construídas durante o seu reinado, o escritor português

\footnotetext{
${ }^{12}$ SARAMAGO, 1983, p.65.

${ }^{13}$ SARAMAGO, 1983, p.169-170.

${ }^{14}$ SILVA, 1989, p.84-85.
} 
dará voz, sobretudo através de Baltasar, aos homens que de fato construíram o convento, aos que sofreram e morreram para a glória de el-rei, personagens que a história oficial não registra em seus compêndios. Ao comentar, por exemplo, a versão segundo a qual "Deve-se a construção do convento por um voto que o rei fez se lhe nascesse um filho", o narrador denuncia "que aqui vão seiscentos homens que não fizeram filho nenhum à rainha, e é eles que pagam o voto, que se lixam, com o perdão da anacrónica voz". ${ }^{15}$ De fato, o narrador "desloca o eixo tradicional da leitura do passado, comprometido com a nobreza e o clero, deixa emergir o povo e aí elege os seus novos heróis, nomeia-os quando o silêncio da história vitoriosa tentara encobrir os seus nomes", ${ }^{16}$ como bem coloca Teresa Cristina Cerdeira da Silva.

Se em linhas gerais essa é a postura de José Saramago diante de personagens e fatos históricos do passado de seu país, veremos que em O ano da morte de Ricardo Reis, de 1984, cujo enredo se desenvolve durante o ano de 1936, não apenas a história do período será revisitada pela pena do escritor, mas também dois grandes mitos da sua cultura passarão por um processo de desconstrução: Fernando Pessoa e Luís de Camões.

\section{A dessacralização de Pessoa e Camões}

O ano de 1936 é de fato o escolhido pelo escritor português para revisitar um período tumultuado não apenas da história de seu país, como também da história da Europa. Estamos no auge da ditadura salazarista, com o nazi-fascismo se espalhando pela Europa, e acompanhando os bastidores da Guerra Civil Espanhola e da Segunda Grande Guerra Mundial. É nesse período conturbado que

\footnotetext{
${ }^{15}$ SARAMAGO, 1983, p.257.

${ }^{16}$ SILVA, 1989, p.34.
} 
terá de viver o heterônimo pessoano, de volta à vida nas páginas do romance de José Saramago.

Ricardo Reis é o poeta criado por Fernando Pessoa e que declara na obra poética por ele assinada, as Odes de Ricardo Reis, que "Sábio é o que se contenta com o espetáculo do mundo". Saramago cria em seu romance situações em que Ricardo Reis é posto em xeque, pois o coloca vivendo numa realidade que, apesar de ser também ficcional, a das páginas de seu romance, no entanto se esteia na vida real, e tem como painel de fundo os acontecimentos do conturbado ano de 1936.

Podemos pensar que o grande alvo do autor de $\mathrm{O}$ ano $\mathrm{da}$ morte de Ricardo Reis é de fato o poeta Fernando Pessoa e muitas das posturas políticas que assumiu em vida. Ele é também personagem do romance, apesar de a história começar aproximadamente um mês após a sua morte. A presença do fantasma de Fernando Pessoa, perambulando pelas ruas de Lisboa, enquanto aguarda que o mundo o esqueça, é justificada por ele próprio, quando diz a Ricardo Reis que antes de virmos ao mundo, nos nove meses que antecedem a nosso nascimento, já pensam em nós, da mesma forma, depois de morrermos, "nove meses é o quanto nos resta antes do total olvido". ${ }^{17}$

Esse Fernando Pessoa que ganha vida nas páginas do romance de José Saramago será totalmente dessacralizado. As calças curtas, "Aquele rosto nu, sem óculos, com o bigode ligeiramente crescido, pêlo e cabelo têm vida mais longa", ${ }^{18}$ como esclarece, a aparência desolada, a incapacidade de leitura, pois, segundo ele, esta é a primeira coisa que perdemos quando morremos, ${ }^{19}$ todos esses elementos de sua caracterização contribuem para uma certa diminuição da imagem do poeta. Se considerarmos, por exemplo,

\footnotetext{
${ }^{17}$ SARAMAGO, 1985, p.80.

${ }^{18}$ SARAMAGO, 1985, p.279.

${ }^{19}$ Cf. SARAMAGO, 1985, p.415.
} 
que a escrita e a leitura são fundamentais na forma como Pessoa interagiu com o mundo, a perda dessa capacidade anula qualquer contato possível que ainda pudesse ter com os vivos, tanto que é Ricardo Reis quem lê para ele os jornais, dando-lhe a chance de prorrogar por mais um período esse contato com um mundo que se esvai aos poucos no tempo que ainda lhe resta antes do total olvido. O narrador do romance, no entanto, vai reforçar que “(...) Fernando Pessoa já não é Fernando Pessoa, e não porque esteja morto, a grave e decisiva questão é que não poderá acrescentar mais nada ao que foi e ao que fez, ao que viveu e escreveu, se falou verdade no outro dia, já nem sequer é capaz de ler, coitado". ${ }^{20}$

O trecho acima sintetiza bem a situação em que um dos maiores poetas da língua portuguesa é retratado nas páginas do romance de Saramago. Fernando Pessoa é reduzido a um "coitado", e, mais que isto, aparece negando, em outros momentos, posturas assumidas em vida. ${ }^{21}$ Porém as críticas a ele não param por aí. Podemos pensar que a censura que o narrador faz a respeito de vários comportamentos do personagem Ricardo Reis tem sempre como alvo o próprio poeta de Orpheu. Um exemplo de como isto ocorre em $\mathrm{O}$ ano da morte de Ricardo Reis nos remete ao famoso verso do heterônimo, já citado anteriormente. O narrador do romance, em determinado momento, diz que Ricardo Reis "é um espectador do espetáculo do mundo, sábio, se isso for sabedoria", ${ }^{22}$

${ }^{20}$ SARAMAGO, 1985, p.91.

${ }^{21}$ Há no romance uma conversa de Reis e Pessoa, entre as várias em que discutem sobre a morte, na qual, ao ser questionado por Reis sobre o ter dito "Neóphito, não há morte", Fernando Pessoa renega o que dissera antes, afirmando que "há morte" (SARAMAGO, 1985, p.275). Logo em seguida, o poeta diz que "vida e morte é tudo um" (p.279). Nesta conversa, como aponta Ricardo Reis, Fernando Pessoa afirma três coisas distintas. Por fim, só resolve "a contradição que as duas primeiras afirmações representavam" ao concluir que "morte e vida são o mesmo" (p.279), para isso negando-se sucessivamente até encontrar um consenso para as suas declarações.

${ }^{22}$ SARAMAGO, 1985, p.90. 
questionando, portanto, através da maneira irônica como parodia o famoso verso, a atitude "alienada", que se depreende de uma leitura das Odes.

Se a obra pessoana acaba sendo revisitada nas páginas desse romance de José Saramago, um outro grande nome da cultura portuguesa também estará sendo aí focalizado de maneira crítica pela pena do escritor português: Luís de Camões.

O romance inicia e termina parodiando o famoso verso de $O s$ Lusíadas, que anuncia a localização do reino lusitano. Para Camões, Portugal fica "Onde a terra se acaba e o mar começa", ${ }^{23}$ que, mais do que uma referência geográfica, anuncia de fato o início do período áureo da história portuguesa, projetado nas conquistas marítimas. No livro de Saramago, esse verso aparece transmudado em dois momentos cruciais da narrativa, como já dissemos, abrindo e fechando o romance. Num primeiro momento, o narrador diz: "Aqui o mar acaba e a terra principia" 24 e, no fim do livro: "Aqui, onde o mar se acabou e a terra espera." 25 Há portanto uma inversão do referencial, pois, para Saramago, Portugal é onde o mar acaba, ou já se acabou, como diz no final de sua obra. Podemos pensar que, contrariamente a Camões, que acreditava estar nas conquistas ultramarinas a possibilidade de grandeza para o seu país, Saramago anuncia que esse período áureo faz parte do passado, e que é para a terra que Portugal deve voltar-se.

Há um outro acontecimento no romance que é revelador dessa desmistificação desses dois importantes personagens da cultura portuguesa. Pensamos aqui num momento em que o narrador põe em cena lado a lado esses dois grandes mitos: Pessoa e Camões. Já havíamos visto que o poeta de Mensagem deambula pelas ruas de Lisboa; quanto a Camões, a sua presença é sempre

\footnotetext{
${ }^{23}$ CAMÕES, 1980, Canto III, estância 20, p.200.

${ }^{24}$ SARAMAGO, 1985, p.11.

${ }^{25}$ SARAMAGO, 1985, p.415.
} 
evocada, sobretudo através da estátua que há em sua homenagem na praça que leva o seu nome. Há, entretanto, um momento em que Fernando Pessoa, sentado num banco dessa praça, tenta se lembrar do poema dedicado a Camões em Mensagem, e descobre surpreso que não há nenhum poema nesta sua obra dedicado ao grande poeta dos quinhentos. A estátua então ganha voz e responde:

(...) Luís de Camões sorri, a sua boca de bronze tem o sorriso inteligente de quem morreu há mais tempo, e diz, Foi inveja, meu querido Pessoa, mas deixe, não se atormente tanto, cá onde ambos estamos nada tem importância, um dia virá em que o negarão cem vezes, outro lhe háde chegar em que desejará que o neguem. ${ }^{26}$

Camões, neste momento, alerta a Fernando Pessoa sobre o risco que se corre depois da morte, sobre a impossibilidade de se controlar o uso que é feito dos atos e obras que deixamos. A respeito dessa passagem, Cerdeira da Silva comenta que

O poeta Jorge de Lima escrevera já: "Estavas, linda Inês, nunca em sossego", agora, quem deseja o sossego já não é a personagem, mas o próprio Camões. Já não pode dizer e é dito por outros, tantas vezes negado, padece mais que o Cristo - negado cem vezes ao invés de três. Transformado, distorcido, é negado em sua verdade. Já não se podendo transformar, alterar a sua escolha, e ainda sujeito à leitura imprópria que dele fazem, quer-se negado. ${ }^{27}$

Essa angústia que a estátua de Camões revela quando ganha voz, já havia passado o personagem Fernando Pessoa, quando, numa conversa hipotética com Ricardo Reis, o ortônimo é questionado sobre algumas posturas assumidas em sua obra. Nesse momento, Pessoa diz que, apesar de morto,

(...) todos os meus actos, todas as minhas palavras, continuam vivos, avançam para além da esquina a que me encosto, vejo-os que partem, deste lugar donde não posso sair, vejo-os, actos e palavras, e não os

\footnotetext{
${ }^{26}$ SARAMAGO, 1985, p.352.

${ }^{27}$ SILVA, 1989, p.181.
} 
posso emendar, se foram expressões de um erro, explicar, resumir num acto só e numa palavra única que tudo exprimissem de mim, ainda que fosse para pôr uma negação no lugar duma dúvida, uma escuridão no lugar da penumbra, um não no lugar de um sim, ambos com o mesmo significado, e o pior de tudo talvez nem sejam as palavras ditas e os actos praticados, o pior, porque é irremediável definitivamente, é o gesto que não fiz, a palavra que não disse, aquilo que teria dado sentido ao feito e ao dito (...). ${ }^{28}$

Como vemos, o Fernando Pessoa personagem do romance de Saramago reconhece melancolicamente que após a morte não pode emendar mais nenhum ato feito ou palavra dita, e, mais que isto, vê que estes continuam vivos, que partem, ganham autonomia. Camões, por sua vez, diz ao poeta do Orpheu que chegará o dia em que desejará ser negado, alertando para o uso que a posteridade fará da obra pessoana, como fez também da sua.

Podemos pensar que a maneira como Saramago os dessacraliza em seu romance, na forma como relê esses dois grandes mitos, é o modo que encontra para negar não só a leitura que Camões e Pessoa fizeram do período áureo da conquistas ultramarinas portuguesas, como sobretudo negar o uso ideológico a que a obra deles foi exposta. A própria obra de Saramago, que se volta para o passado "com os olhos fitos no presente", também está e estará sujeita a várias leituras e, quiçá, o seu autor desejará um dia também ser negado, do mesmo modo como ansiaram os seus companheiros das letras nas páginas de O ano da morte de Ricardo Reis.

Se, como estamos procurando apontar, o autor de Memorial do convento, trata sempre de maneira desmistificadora seja as grandes personagens da história ou da vida literária portuguesa, ele, no entanto, não vai se esquecer de uma figura que é central para a formação e compreensão da sociedade ocidental em que vive. Estamos nos referindo, obviamente, ao seu romance $O$ Evangelho segundo Jesus Cristo, de 1991, a respeito do qual falaremos a seguir.

${ }^{28}$ SARAMAGO, 1985, p.147-148. 


\section{Um apócrifo contemporâneo}

Em determinado momento de O Evangelho segundo Jesus Cristo, o narrador parece fazer um pacto com o leitor, como se pretendesse manter-se fiel em relação à tradição bíblica, ao dizer que é "Jesus o evidente herói deste evangelho, que nunca teve o propósito desconsiderado de contrariar o que escreveram outros e portanto não ousará dizer que não aconteceu o que aconteceu". ${ }^{29}$

É evidente que esta afirmação é um blefe do narrador. Isto porque justamente o que nega neste instante, ou seja, "contrariar o que escreveram outros", é o que mais faz neste seu romance, sobretudo se pensarmos que os outros, a que se refere, sejam os autores dos Evangelhos canônicos.

Se, por um lado, conserva em parte a tradição bíblica - como a versão de que Jesus nasceu em Belém, ou sua discussão, aos treze anos, com os doutores na sinagoga, ou narrando muitos dos milagres a ele atribuídos, por outro lado, além de abordar de modo muito particular alguns dados desta tradição, acrescenta elementos novos que, em outros tempos, colocariam o seu livro no Índex.

Entre esses elementos vemos, por exemplo, Cristo unir-se e viver maritalmente com Madalena até o momento da crucificação; e se, como dissemos, são narrados muitos dos milagres que constam dos Evangelhos, entretanto uma nova versão ou interpretação é dada a eles.

O episódio em que Jesus amaldiçoa a figueira, por exemplo, terá um tratamento novo nas páginas do romance de José Saramago. Em Mateus e Marcos, Cristo age assim pois tem fome e pune, de certa forma, a árvore por esta não ter frutos. Diante da surpresa dos discípulos, diz que o fato de a figueira ter secado é um exemplo da capacidade da fé (Mt 21, 18-22; Mc 11, 12-14). Já em O Evangelho segundo Jesus Cristo, Maria de Magdala, que acompanha Jesus, o censura pelo ato cometido:

${ }^{29}$ SARAMAGO, 1991, p.239-240. 
Ia Jesus por um caminho no campo quando sentiu fome, e vendo ao longe uma figueira com folhas, foi ver se nela encontraria alguma coisa, mas, ao chegar ao pé dela, não encontrou senão folhas, pois não era tempo de figos. Disse então, Nunca mais nascerá fruto de ti, e naquele mesmo instante secou a figueira. Disse Maria de Magdala, que com ele estava, Darás a quem precisar, não pedirás a quem não tiver. Arrependido, Jesus ordenou à figueira que ressuscitasse, mas ela estava morta. $^{30}$

Como vemos, Madalena é quem tem razão, ao mostrar-lhe que a árvore não tem culpa de não ter frutos naquela época do ano. Jesus então se arrepende, mas não consegue reverter o seu ato.

Outro "milagre" que é, de certa forma, contestado na nova versão de Saramago é o da expulsão dos demônios de um homem possesso. O episódio, segundo os Evangelhos canônicos, tem poucas variações. Segundo Marcos (5, 1-20) e Lucas (8, 26-39), que mais coincidem entre si, e é a versão mais próxima da narrada por José Saramago, Jesus, acompanhado de alguns discípulos, vai até a região dos gadarenos e lá é atacado por um homem possesso. Os demônios, que se auto-denominam Legião, pois são muitos, chamam-no de filho de Deus e pedem que ele os expulse para uma vara de porcos. Depois disso feito, os animais se atiram ao mar e acabam por morrer afogados. A perda dos animais causa a ira de seus donos, que, como represália, expulsam Jesus e os seus companheiros da região.

A versão de José Saramago, apesar de ser fiel ao cânone, apresenta uma nova interpretação para esse acontecimento. Além de o narrador sugerir que Jesus não previu que os gentios, donos dos porcos, poderiam vir a comê-los e assim ficarem também possessos, o próprio Jesus acaba por perceber que o seu ato resultou na morte inútil dos animais, pois, como os demônios são imortais, estes tornaram-se livres após a morte dos bichos:

Jesus (...) via o mar, os porcos flutuando e baloiçando-se na ondulação, dois mil animais sem culpa, uma inquietação germinava dentro de si,

${ }^{30}$ SARAMAGO, 1991, p.361-362. 
buscava por onde romper, e de súbito, Os demónios, onde estão os demónios, gritou, e depois soltou uma gargalhada para o céu, Escutame, ó Senhor, ou tu escolheste mal o filho que disseram que eu sou e há-de cumprir os teus desígnios, ou entre os teus mil poderes falta o duma inteligência capaz de vencer o diabo, Que queres dizer, perguntou João, aterrado pelo atrevimento da interpelação, Quero dizer que os demónios que moravam no possesso estão agora livres, porque os demónios já nós sabíamos que não morrem, meus amigos, nem sequer Deus os pode matar, o que eu ali fiz valeu tanto como cortar o mar com uma espada. ${ }^{31}$

Um outro episódio bíblico, o da ressurreição de Lázaro, que é narrado no Evangelho de João (11, 1-44), é negado na versão de José Saramago e tem uma participação decisiva de Maria de Magdala.

Em O Evangelho segundo Jesus Cristo, Maria é irmã de Marta e de Lázaro. ${ }^{32}$ Jesus, por viver com Maria, acaba conhecendo a sua família e afeiçoando-se a esta. Lázaro, porém, é muito doente e Jesus, para demonstrar o seu afeto por ele, o cura. ${ }^{33}$ Entretanto, algum tempo depois Lázaro vem de fato a morrer, como narra a tradição, e Jesus decide então ressuscitá-lo. Maria, porém, intervém dizendo que "Ninguém na vida teve tantos pecados que mereça morrer duas vezes". ${ }^{4}$ Jesus, prostrado, concorda com ela e não ressuscita Lázaro.

${ }^{31}$ SARAMAGO, 1991, p.356-357.

${ }^{32}$ Aliás, considerar as duas Marias, a de Betânia e a de Magdala, como a mesma pessoa, não é exclusividade da obra de José Saramago. Outros já aventaram esta hipótese. O Frei Mateus Hoepers, tradutor do Novo Testamento que estamos utilizando, em nota afirma que "a misericórdia de Jesus para com as mulheres pecadoras" resultou na "opinião tradicional dos Santos Padres gregos e latinos da identidade de pessoa entre a pecadora, Maria de Betânia, irmã de Marta, e Maria Madalena" (Novo Testamento, 1975, p.87). Em O Santo Graal e a Linhagem Sagrada, os autores também levantam a hipótese de que Maria Madalena e Maria, irmã de Marta e Lázaro, seriam a mesma pessoa (cf. BAIGENT et alli, 1993, p.273-280).

${ }^{33}$ Cf. SARAMAGO, 1991, p.412-413.

${ }^{34}$ SARAMAGO, 1991, p.428. 
Esses fatos nos mostram que estamos diante de uma versão não ortodoxa da vida de Cristo, mas não são os únicos. No início do romance, ao falar do anjo que anuncia a Maria a sua gravidez, o narrador o faz de maneira totalmente diversa do modo como a tradição fixou esse episódio. Não só Maria não é mais virgem, como sabe que está grávida de José e apenas espera o momento certo para contar a ele a novidade, quando o anjo, sob a forma de um mendigo, lhe aparece. Mesmo as palavras com que ela lhe teria respondido, como podemos ver em Lucas $(1,38)$, serão ditas bem mais tarde, depois que Jesus, já adulto, confirmar para a mãe que é filho de Deus, e o anjo aparecer a ela novamente; é então que Maria diz: "sou realmente a escrava do Senhor, cumpra-se em mim segundo a sua palavra".35

Porém, o que torna mais heterodoxa essa versão do episódio da anunciação é que depois saberemos que esse anjo, que aparece às vezes como um mendigo ou como um pastor, na realidade é o diabo, personagem que terá uma participação decisiva na história, sempre acompanhando de perto a vida de Jesus. Aparecerá, por exemplo, como um dos "três reis magos" que visitarão o menino recém-nascido. Mais importante, no entanto, será o papel que assumirá mais tarde: o de mentor de Jesus, quando este, após abandonar a família, vive como um pastor até se encontrar pela primeira vez com Deus, que lhe anuncia a missão para a qual está predestinado.

Se esse anjo/demônio já nos mostra a forma radicalmente heterodoxa como o autor de O Evangelho trata a vida de Jesus, muito mais fará com a imagem de Deus. Como admite em uma de suas entrevistas, Saramago diz que neste seu romance Deus "é de facto o mau da fita”, ${ }^{36}$ pois considera que ele

\footnotetext{
${ }^{35}$ SARAMAGO, 1991, p.314.

${ }^{36}$ SARAMAGO apud Vasconcelos, 1991, p.8.
} 
é a encarnação do Poder (...). E quando o Poder, (além de ser naturalmente antipático) se exerce de uma forma tão autoritária, tão opressiva, como na relação de Deus com Jesus, quando sabemos tudo que se vai passar em sofrimento, em horror, em renúncias, em sacrifício, em torturas, em tudo aquilo, além do que de positivo teve - que foi a história do Cristianismo, dá vontade de tratar - a mim deu-me - Deus como o grande responsável. ${ }^{37}$

Para executar esse seu objetivo, Saramago parte não só das explanações do narrador, mas também utiliza os próprios personagens para questionar os desígnios divinos. Ainda no início da história, o narrador diz "que Deus, se de algo sabe, é dos homens, e mesmo assim não de todos, que sem conta são os que vivem como burros, ou ainda pior, e Deus não tem curado de averiguar e prover". ${ }^{38}$ Se neste momento questiona a sapiência e a onipresença de Deus, uma crítica muito mais veemente fará ao mostrá-lo intransigente e disposto a tudo para ampliar seu império religioso. Assim, quando Jesus toma conhecimento das milhares de mortes necessárias para a edificação da Igreja construída em seu nome, e se desespera, e o Diabo decide que para evitar tanto sofrimento abdicaria de ser o mal, Deus não aceita e responde:

Não te aceito, não te perdoo, quero-te como és, e, se possível, ainda pior do que és agora, Porquê (pergunta o Diabo), Porque este Bem que eu sou não existiria sem esse Mal que tu és (...), para que eu seja o Bem, é necessário que tu continues a ser o Mal, se o Diabo não vive como Diabo, Deus não vive como Deus, a morte de um seria a morte de outro (...). ${ }^{39}$

O próprio Cristo será um dos que de maneira mais incisiva questionará os projetos divinos e tentará burlar o que lhe está predestinado: tentará transformar o seu crime num crime político, assumindo-se, diante de Pilatos, não como o filho de Deus, mas como o rei dos Judeus. Quando percebe que o seu sacrifício foi em

\footnotetext{
${ }^{37}$ SARAMAGO apud VASCONCELOS, 1991, p.8.

${ }^{38}$ SARAMAGO, 1991, p.77.

${ }^{39}$ SARAMAGO, 1991, p.392-393.
} 
vão, já que Deus aparece no momento da crucificação e anuncia a todos que ele é seu filho, Jesus declara: "Homens, perdoai-lhe, porque ele não sabe o que fez". ${ }^{40}$

Assim, se neste romance Saramago resgata, de certa forma, a figura de Cristo, humanizando-o, mostrando-o como uma vítima, como um cordeiro levado ao sacrifício para que seu Pai alcance uma glória que o próprio filho considera insana, nenhuma complacência terá para com Deus, afinal este é considerado como o único responsável pelo "rio de sangue e de sofrimento que (...) irá nascer e alagar toda a terra". ${ }^{41}$

Como podemos ver, parece claro que José Saramago opta, no seu Evangelho, em redimir Cristo de culpas. Se decidiu dessacralizálo, tornando-o humano, mostrou também que não lhe é dado o direito de livre-arbítrio. Curiosamente coloca num ser com poderes sobre-humanos, com os quais o homem não pode lutar, a responsabilidade de tudo o que condena.

Se, em seus outros romances, parecia generalizar suas críticas à Igreja Católica, seus membros e dogmas, em O Evangelho segundo Jesus Cristo seu principal alvo é um personagem em que, como tem dito, não crê. Portanto, neste romance, Saramago deixa de lutar contra a instituição religiosa, criada pelos homens, e concentra seus ataques àquele que a fundamenta: o próprio Deus.

\section{Conclusão}

Para concluir a nossa leitura desses três romances de José Saramago, gostaríamos de salientar que a obra deste escritor tem caminhado no sentido de uma universalidade. Seus romances anteriores à publicação do Evangelho, em 1991, falavam sempre de

\footnotetext{
${ }^{40}$ SARAMAGO, 1991, p.444.

${ }^{41}$ SARAMAGO, 1991, p.444.
} 
Portugal, ou no máximo da Península Ibérica, como ocorre em $A$ jangada de pedra, revelando claramente uma preocupação do escritor em rever o passado de seu país. Já o Evangelho segundo Jesus Cristo parece ser um marco divisor, pois é uma obra que não interessa apenas a Portugal, país de forte tradição católica, mas a toda cultura ocidental, que é tributária do cristianismo. Seus últimos dois romances, Ensaio sobre a cegueira, de 1995, e Todos os nomes, de 1997, trabalham com temáticas universais. Primeiramente não há com exatidão uma definição de local e data onde as histórias se passam; os personagens deixam de ter nomes próprios e passam a ser designados por alguma característica que lhe são peculiares: tipo físico, onde moram, profissão, etc. Em Todos os nomes, apenas o protagonista é nomeado, senhor José, e o livro fala da sua solidão e do sem sentido de sua vida, destacando também o nonsense da hierarquia e da burocracia, que regem muitas das relações sociais. Por sua vez, no Ensaio sobre a cegueira, temos uma crítica mordaz à sociedade humana, à sua cegueira, pois, mesmo podendo enxergar, não somos capazes de ver. Já a epígrafe que abre o romance, tirada de um fictício "Livro dos Conselhos", criado pelo próprio Saramago, adverte: "Se podes olhar, vê. Se podes ver, repara". Esta epígrafe pode servir para orientar a leitura de qualquer romance desse escritor, pois ao rever a história de Portugal, ou de boa parte da humanidade, através da releitura que faz do cristianismo, ou ao criticar os caminhos de nossa sociedade no fim deste século, o que este autor parece querer dizer, a nós leitores, com o seu olhar crítico seja sobre o passado, seja sobre o presente, é que é necessário mais que olhar, mais que ver, é preciso sobretudo reparar, nos dois sentidos que esta palavra possa ter: o de prestar bastante atenção e o de agir, ou seja, reparar, consertar as coisas erradas do mundo que vivemos. 


\section{Referências Bibliográficas}

BAIGENT, Michael, LEIGH, Richard, LINCOLN, Henry. O Santo Graal e a linhagem sagrada. Rio de Janeiro: Nova Fronteira, 1993. CAMÕES, Luís de. Os Lusíadas. Rio de Janeiro: Biblioteca do Exército, 1980.

DUARTE, Lélia Parreira, et alii. José Saramago, tecedor da história. Boletim do Centro de Estudos Portugueses, UFMG, ano IX,X, n.12. p.90-100.

HOEPERS, Mateus. Introdução e notas. In: Novo Testamento. 11. ed. Petrópolis: Vozes, 1975.

Novo Testamento. 11. ed. Petrópolis: Vozes, 1975.

PESSOA, Fernando. Obra poética.9.ed. Rio de Janeiro: Nova Aguilar, 1983.

SARAIVA, José Hermano. História concisa de Portugal. Lisboa: Europa-América, 1978.

SARAMAGO, José. História do cerco de Lisboa. São Paulo: Companhia das Letras, 1989.

SARAMAGO, José. Levantado do chão. São Paulo: DIFEL, 1982.

SARAMAGO, José. Memorial do convento. São Paulo: DIFEL,1983.

SARAMAGO, José. O ano da morte de Ricardo Reis. 6.ed. Lisboa: Ed.Caminho, 1985.

SARAMAGO, José. O Evangelho segundo Jesus Cristo. São Paulo: Companhia das Letras, 1991.

SARAMAGO, José. História e ficção. Jornal de Letras, Artes e Ideias. Lisboa, 6-3-1990. p.17-20.

SARAMAGO, José. Ensaio sobre a cegueira. São Paulo: Companhia das Letras, 1995.

SARAMAGO, José. Todos os nomes. São Paulo: Companhia das Letras, 1997.

SERRÃO, Joel. Dicionário de história de Portugal (vol.3). Lisboa: Figueirinhas/Porto, 1971. 
SILVA, Teresa Cristina Cerdeira da. José Saramago. Entre a história e a ficção: uma saga de portugueses. Lisboa: Dom Quixote, 1989.

VASCONCELOS, José Carlos de. José Saramago: "Deus é o mau da fita". Jornal de Letras, Artes e Ideias, Lisboa, p.8-10, 5-11-1991.

\section{Resumo}

Este texto procura analisar três romances de José Saramago, Memorial do convento, $O$ ano da morte de Ricardo Reis e $O$ Evangelho segundo Jesus Cristo, destacando como nesses romances são desmistificados importantes personagens não só da cultura portuguesa, como também da civilização ocidental.

\section{Abstract}

This work intends to analyze three José Saramago's novels: Memorial do convento, $O$ ano da morte de Ricardo Reis and $O$ Evangelho segundo Jesus Cristo, and tries to show how, in those books, important cultural figures, not only Portuguese, but also occidental ones, has been dismystified. 